Est Ag 52 (2017) 207-240

\title{
El bautismo de Felipe, ¿un bautismo deficitario? (Hch 8,5-24)
}

\author{
DAVID ÁlVAREZ CineIRA
}

RESUMEN: En el relato de la actividad bautista de Felipe en Samaría (Hch 8,425) sorprende que no esté explícitamente vinculada a la concesión del Espíritu, a pesar de que se realiza en el nombre del Señor Jesús y como tal constituye un bautismo cristiano "legítimo". Probablemente el texto refleje una de las diferentes praxis bautismales existentes en el cristianismo de los orígenes y subyazcan aquí tradiciones bautismales propias de grupos helenistas cristianos, que Lucas recogió e integró en su relato.

Palabras clave: Bautismo, Felipe, helenistas, samaritanos, efusión del Espíritu

ABSTRACT: In the story of the baptismal activity of Philip in Samaria (Acts 8:425 ) it is surprising that it is not explicitly linked to the granting of the Spirit, even though it is performed in the name of the Lord Jesus and as such constitutes a "legitimate" Christian baptism. Probably the text reflects one of the different baptismal praxis existing in the origins of Christianity and underlies here baptismal traditions proper of Hellenistic Christian groups, that Lucas collected and integrated in his pericope.

Keywords: Baptism, Philip, Hellenists, Samaritans, outpouring of the spirit, laying on of hands.

La primera parte del libro de Hechos ${ }^{1}$ se caracteriza por una elevada concentración de narraciones bautismales: Pentecostés, el bautismo de los samaritanos y Simón el Mago, así como el del etíope (8,26-40), el de

${ }^{1}$ La monografía fundamental sobre este tema es la de Avemarie, Friedrich, Die Tauferzählungen der Apostelgeschichte. Theologie und Geschichte (=WUNT 139), Mohr Siebeck, Tübingen 2002. Véase también Quesnel, Michel, Baptisés dans l'Esprit. Baptême 
Saulo $(9,10-18)$ y, por último, el bautismo de los reunidos en casa de Cornelio $(10,24-48)$. Estos relatos detallados tienen como objetivo mostrar la expansión y difusión del testimonio de Cristo hasta Antioquía, es decir, pertenecen al contexto del crecimiento numérico y geográfico de la Iglesia. Posteriormente solo aparecerán algunas breves notas sumariales sobre el bautismo de Lidia con su casa en Filipos $(16,15)$, el del carcelero $(16,33)$, y que muchos de los corintios creyeron y fueron bautizados $(18,8)$. Una posición especial adquiere el bautismo de los discípulos de Juan en Éfeso (19,1-7), que -aparte de la retrospectiva de Pablo de su propio bautismo en 22,16- constituye la última mención del bautismo en Hechos.

De entre esas narraciones destacan Pentecostés en Jerusalén (Hch 2) y la efusión del Espíritu sobre los gentiles en casa de Cornelio (Hch 10-11), relatos que muestran una estrecha conexión entre la efusión del Espíritu Santo y el bautismo. Esta relación viene asimismo remarcada en los pasajes del bautismo administrado por Felipe a los samaritanos y el de los doce discípulos que Pablo encuentra en Éfeso. Si para Lucas es crucial que el bautismo cristiano y la recepción del Espíritu vayan de la mano, sin embargo es sorprendente que el bautismo administrado por Felipe a los samaritanos sea deficitario e incapaz de transmitir el Espíritu ("pues aún no había venido sobre ninguno de ellos" v. 16). Su bautismo se realiza en el nombre del Señor Jesús (v. 16) y, como tal, es un bautismo cristiano "legítimo". No obstante, será la llegada de los apóstoles Pedro y Juan y la imposición de sus manos las que posibiliten la recepción del Espíritu (v. 17). ¿Cómo explicar esta "anomalía” bautismal?

El presente artículo abordará esta dificultad. Para ello presentamos, en primer lugar, la estructura narrativa del pasaje, así como la labor redaccional de Lucas, lo que nos posibilitará comprender la problemática

et Esprit Saint dans les Actes des Apôtres, Éd. du Cerf, Paris 1985; Kıм, H.-S., Die Geisttaufe des Messias. Eine kompositionsgeschichtliche Untersuchung zu einem Leitmotiv des lukanischen Doppelwerks. Ein Beitrag zur Theologie und Intention des Lukas (=SklPhil 81), Lang, Frankfurt am Main 1993; así como Ferguson, Everett, Baptism in the Early Church. History, Theology, and Liturgy in the First Five Centuries, William B. Eerdmans, Grand Rapids, Mich. 2009, 166-185; BAUMERT, Norbert, Charisma - Taufe - Geisttaufe. Bd. II: Normativität und persönliche Berufung, Echter, Würzburg 2001, 107-118; BARTH, Gerhard, Die Taufe in frühchristlicher Zeit, 2. verbesserte Auflage, Neukirebener Verlag, Neukirchen-Vluyn 2002, 55-66; Wainwright, Geoffrey, "Baptism, Baptism Rites", en Martin, Ralph P. - Davids, Peter H. (eds.), Dictionary of the Later New Testament and its Developments, IVP, Downers Grove, IL 1997, 112-125; Cullmann, Oscar, Baptism in the New Testament (SET, 1), SCM Press - Westminster Press, London - Philadelphia 1950; Beasley-Murray, George Raymond, Baptism in the New Testament, Paternoster Press, Carlisle 1997 (original 1962), 104-125. 
que subyace mejor su percepción bautismal y explicar el bautismo de Felipe. En un segundo momento se expone, de forma muy sucinta, la relación intrínseca del rito iniciático con la recepción del Espíritu en la concepción lucana de Hechos y su vinculación al rito de la imposición de manos. La anomalía de la separación del bautismo y la recepción del Espíritu ha propiciado muy variadas explicaciones, como se mostrará en una sección (IV) y concluiremos con la propuesta de que Hch 8,5-25 conserve el rito bautismal proveniente del cristianismo helenista y del que Felipe era uno de sus misioneros.

Tal vez el estudio de este pasaje corrobore las palabras que Senén Vidal afirmaba en uno de sus últimos libros, Hechos de los apóstoles y orígenes cristianos, acerca de la imagen mucho más viva y variada del cristianismo de los orígenes: "la historia real del cristianismo primitivo fue mucho más diferenciada que la imagen de unidad compacta que presenta el autor de Hechos. Los datos de las antiguas tradiciones cristianas apuntan claramente a diversas corrientes cristianas desde los mismos orígenes del movimiento cristiano y a diversas actitudes dentro de ellas" 2 . A su memoria van dedicadas estas páginas en sentido de gratitud por todo lo que nos enseñó y compartió. ¡Gracias!

\section{COMPOSICIÓN DE LA ESCENA DE LA CONVERSIÓN DE LOS SAMARITANOS}

Tras la persecución desencadenada contra la Iglesia de Jerusalén, todos, excepto los apóstoles, se dispersaron por las regiones de Judea y Samaría, quienes anunciaban el mensaje por todas partes. Es precisamente en estas circunstancias, cuando Hechos pone en escena a un personaje, Felipe, que proclama un mensaje idéntico al de Jesús en el evangelio de Lucas y realiza milagros equivalentes, pero va más allá de los límites del territorio de Jesús, al convertirse en el primer misionero en Samaría. Que este significativo avance misionero venga asignado a una figura aparentemente menor, pudiera hacernos pensar que Lucas estaba en posesión de una tradición previa acerca de las actividades de Felipe en Samaría. El hecho de que tal tradición existiera bajo el nombre de Felipe y permane-

\footnotetext{
2 VIDAL, Senén, Hechos de los Apóstoles y orígenes cristianos (=Presencia Teológica 224), Sal Terrae, Maliaño 2015, 168. Un estudio detallado de los relatos bautismales constataría que Hechos contiene una amplia gama de narraciones bautismales, lo cual viene corroborado a su vez por la coordinación variable de la recepción del Espíritu, imposición de manos y bautismo, además de la diferencia entre un bautismo de agua y un bautismo de Espíritu (Hch 1,5; 11,16; 19,1-7).
} 
ciera en circulación en tiempos de Lucas posiblemente indique que la versión pre-lucana consideró a este personaje como fundador de alguna comunidad cristiana de la zona. Sin embargo, no es sencillo individuar las tradiciones empleadas por Lucas, pues un examen detallado del lenguaje utilizado demuestra la naturaleza lucana del relato en su forma actual, aunque a su vez resalta ciertas características que apuntan a la naturaleza de la tradición que Lucas utilizó para construir su versión actual de los acontecimientos. Una vez identificados esos datos, presentaré algunos intentos académicos de evaluar la naturaleza de la tradición y la redacción.

\section{Estructura y composición del relato}

La narración se divide en diversas escenas y, aunque no todos los comentarios coinciden, se puede proponer la siguiente estructura:

$\begin{array}{lll}\text { Introducción: } & 8,4 & \text { Los dispersados (cf. 8,1; 11,19) } \\ \text { 1 }^{\text {a }} \text { Escena } & 8,5-8 & \text { Felipe en Samaría (cf. 1,8; 6,5) } \\ & 8,9-11 & \text { Simón en Samaría } \\ & 8,12-13 & \text { Felipe y Simón } \\ \text { 2 } & 8,14-17 & \text { Los apóstoles en Samaría } \\ & 8,18-24 & \text { Simón y Pedro (y Juan) } \\ \text { Sumario conclusivo } & 8,25 & \text { Los apóstoles en Samaría }\end{array}$

Tres escenas componen el relato de la actividad de Felipe en Samaría: (1) la historia de su llegada y exitosa misión en Samaría (5-8), (2) el éxito previo de Simón el Mago y enfrentamiento de Felipe con Simón (911) y (3) la conversión de los samaritanos y Simón ${ }^{3}$ gracias a Felipe (1213). Por su parte, la segunda escena consta de dos unidades: a) Pedro y Juan llegan desde Jerusalén a Samaría e imponen las manos a los samaritanos, ya que todavía no habían recibido el Espíritu (14-17), b) la unidad final expone el intento fallido de Simón por comprar a Pedro el poder de otorgar el don de Dios (18-24). La perícopa concluye con un sumario de

3 Sobre Simón, cf. HAAR, Stephen, Simon Magus. The First Gnostic (=BZNW 119), Walter de Gruyter, Berlin - New York 2003; HeInTZ, Florent, Simon "le magicien". Actes 8,5-25 et l'accusation de magie contre les prophètes thaumaturges dans l'antiquité (=Cahiers de la Revue Biblique 39), J. Gabalda, Paris 1997. 
la actividad de los apóstoles en muchas aldeas samaritanas en su regreso hacia Jerusalén.

El estilo y el vocabulario lucano impregnan un relato que sirve para su propósito narrativo ${ }^{4}$, en cuanto que traslada la historia de la expansión del cristianismo desde Jerusalén a Samaría y prepara el camino para llevar el evangelio hasta los confines de la tierra, tal como había predicho en Hch 1,8. En particular, la aparición de una forma introductoria típicamente lucana, constituyendo una inclusión de los v. 4-5 (predicar la palabra) y el v. 25 (predicar el evangelio), indica que Hch 8,4-25 constituye una unidad literaria independiente. Otros rasgos corroboran esa unidad:

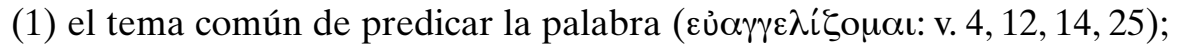

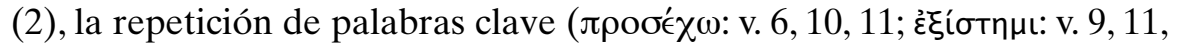

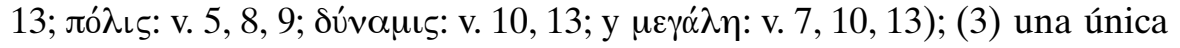
localidad geográfica (Samaría: v. 5, 9, 14 [25]); (4) una estructura que presenta el material narrativo dentro de un patrón alternante, primero entre Felipe y Simón, y luego entre Pedro y Simón [a-b-a-b-c-b-c-b]; (5) referencias únicas a Felipe y Simón, quienes no aparecerán juntos en ninguna otra secuencia de Hechos.

Sin embargo, a pesar de estos elementos típicamente lucanos, los críticos de las fuentes y de la redacción han constatado una serie de llamativas incongruencias en esta unidad narrativa que traicionan posiblemente la reelaboración de tradiciones previas, ya fueran estas orales o escritas: (a) El enfoque cambia de Felipe, protagonista en 8,5-13, a Pedro, quien asume esa posición en 8,14-25, y la presencia de Simón en ambos episodios; (b) la extraña interrupción de la secuencia temporal referente a Felipe mediante un informe sobre las actividades previas de Simón (8,9-11); (c) el hiato creado en 8,14-17 entre el bautismo y la recepción del Espíritu: sin mencionar a Felipe después del v. 13, Pedro y Juan llegan de Jerusalén y son instrumentos en la recepción del Espíritu por parte de los samaritanos, que curiosamente no había acontecido en su bautismo "en el nombre del Señor Jesús"; (d) la descripción de Simón en el v. 13 como alguien que ha sido bautizado y sigue de cerca a Felipe, está en marcado contraste con el ansia personal de poder en v. 19-22; (e) Hch 8,5-13 y 26-40 presentan un material

${ }^{4}$ Para una discusión sobre los elementos de estilo lucano, cf. LÜDEMANN, Gerd, Das frühe Christentum nach den Traditionen der Apostelgeschichte. Ein Kommentar, Vandenhoeck \& Ruprecht, Göttingen 1987, 99-103.

5 Roloff, Jürgen, Hechos de los Apóstoles, Ed. Cristiandad, Madrid 1984, 181: "Esta claridad de la división en escenas hace más llamativas las incongruencias y las rupturas en el curso de[1] relato. Precisamente aquí está la clave para reconstruir la tradición prelucana". 
único de Felipe, mientras que los v.14-25 contienen información que se conservaría mejor en un ciclo de historias petrinas; (f) la cuestión de la recepción del Espíritu planteada en 14-25 aparece también en otro relato petrino (Hch 10,44-48), mientras que esa temática no se plantea en el ciclo de Felipe de las historias en 8,5-13 y 26-40; (g) la aparición de dos expresiones inusuales en los versículos 5-13: Felipe proclama tòv Xpıotóv en Samaría $(8,5)$, y la combinación inusual de predicar la buena nueva del reino de Dios y del nombre de Jesucristo $(8,12)$.

Estas fisuras redaccionales se explicarían por el uso de elementos tradicionales que Lucas reelaboró. Además, el simple hecho de la inclusión de Felipe en la narración, ya indica que Lucas poseía material tradicional sobre la actividad y el significado de este personaje. De lo contrario, la inclusión de estos episodios, que no tienen un efecto apreciable en el curso posterior de la narración, sería inexplicable. Sin embargo, el redactor reelaboró sus materiales de tal forma que en la actualidad son difícilmente identificables y separables los elementos provenientes de la tradición y los de la composición redaccional ${ }^{6}$. Así pues, pasar del empleo probable de material tradicional relativo a Felipe a una delineación de su forma, contenido y Sitz im Leben presenta al intérprete un desafío inmenso, como constataremos a continuación.

\section{La labor redaccional lucana}

¿Cómo y en qué medida Lucas se apropió de tradiciones en la elaboración de 8,5-25? En la historia de la erudición se ha vertido mucha tinta para intentar explicar las curiosidades y los problemas presentes en este texto, especialmente referentes a la relación entre las fuentes empleadas y la redacción lucana del pasaje ${ }^{7}$. Algunos estudiosos han supuesto una tradición exclusivamente petrina, otros han insistido en que el núcleo

${ }^{6}$ Una excepción constituye Witherington, Ben III, The Acts of the Apostles. A Socio-Rhetorical Commentary, William B. Eerdmans - Paternoster Press, Grand Rapids, Michigan / Cambridge - Carlisle 1998, 280s, para quien el autor de Hechos se encontraba con Pablo cuando el apóstol visitó a Felipe y/o a sus hijas (Hch 21,8-11), por lo que sería innecesario postular fuentes escritas, a no ser las propias memorias o notas de Lucas, o suponer una larga historia de la transmisión y edición de este material. De hecho, este material, en varios puntos, no parece haber recibido un buen trabajo editorial, si es que recibió alguno, y ciertamente no una revisión estilística final.

7 Para el antiguo problema de la identificación de las fuentes en Hechos, cf. Dupont, Jacques, The Sources of Acts: The Present Position, Darton, Longman \& Todd, London 1964, 39; Haenchen, Ernst, Die Apostelgeschichte (=KEK 3), Vandenhoeck \& Ruprecht, 
de este pasaje se remonta a una tradición de la actividad de Felipe en Samaría. Otros han propuesto varias combinaciones de tradiciones relacionadas con Felipe, Pedro y Simón. Con tino afirmó C.K. Barrett: "Intentar esto es tomar conciencia de una serie compleja de problemas literarios e históricos. ¿Qué fuentes usó Lucas? ¿Cómo las combinó? ¿Cuál era su valor histórico y hasta qué punto habían conservado el valor histórico que poseían originalmente o por el contrario se destruyó en el proceso editorial? Estas no son cuestiones que puedan ser contestadas con seguridad, y quienes las discuten deben recordar que suelen conjeturar o plantear hipótesis, incluso cuando sus conjeturas son guiadas por la observación y la probabilidad"8.

No obstante esta dificultad, es interesante exponer cómo los eruditos han intentado individuar las diferentes tradiciones empleadas por Lucas. Así Hans Waitz ${ }^{9}$, en un ejemplo clásico de estudios antiguos de crítica de las fuentes, intenta demostrar la existencia de un "documento base" petrino que subyace en el relato de 8,5-25. Su conclusión fue que los versículos 5-13 originalmente describían actividades de Pedro y se atribuyeron secundariamente a Felipe: Lucas se vio obligado a reemplazar a Pedro por Felipe, dado que según él los apóstoles permanecieron en Jerusalén en el momento de la persecución $(8,1)$.

Por su parte, Julius Wellhausen ${ }^{10}$ toma una posición diametralmente opuesta a la de Waitz, ya que Pedro sería un "intruso literario" en un pasaje dedicado originariamente a Felipe. Argumentó que el v. 18b origi-

Göttingen 13 1961, 73-81; Fitzmyer, Joseph A., Los Hechos de los Apóstoles. I: Traducción, introducción y comentario (Hch 1,1-8,40) (=BEB 112), Sígueme, Salamanca 2003, 130-142; y con referencia a Hch 8,4-25, BARretr, Charles K., A Critical and Exegetical Commentary on the Acts of the Apostles. Preliminary Introduction and Commentary on Acts I-XIV, T\&T Clark, Edinburgh 1994, 395ss.; Dickerson, Patrick L., "The Sources of the Account of the Mission to Samaria in Acts 8:5-25", en Novum Testamentum 39 (1997) 210-234.

${ }^{8}$ BARrett, Charles K., "Light on the Holy Spirit from Simon Magus (Acts 8:4-25)", en Kremer, Jacob (ed.), Les Actes des apôtres. Traditions, redáction, théologie (=BETL 48), Leuven University Press, Leuven 1979, 281-295, 284. Semejante opinión expresa JERVELL, Jakob, Die Apostelgeschichte (=KEK 3), Göttingen, Vandehoeck \& Ruprecht 1998, 267, a pesar de la conexión de varias tradiciones, la multiplicidad de hipótesis en conflicto demuestra que la estratificación de la historia de la tradición es incierta y apenas se puede clarificar. En la actualidad no se puede determinar si las diferentes tradiciones o algunas de ellas fueron relacionadas por Lucas o si él ya encontró unidas todas ellas en un contexto narrativo, pues la perícopa ha sido ampliamente reelaborada por el redactor, tanto a nivel lingüístico como de contenido.

9 WaITZ, Hans, "Die Quelle der Philippusgeschichten in der Apostelgeschichte 8,540", en ZSW 7 (1906) 340-355.

10 Wellhausen, Julius, Kritische Analyse der Apostelgeschichte (=AGWG.PH 15/2), Weidmannsche Buchhandlung, Berlin 1914, 15. 
nalmente seguía al "asombro" de Simón en 8,13, y la fuente de Lucas contenía una crónica de la oferta de dinero de Simón a Felipe por la

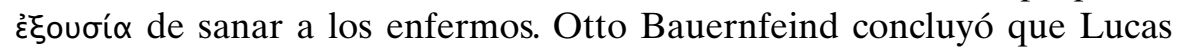
fusionó un relato del éxito misionero de Felipe en Samaría con un testimonio sobre un encuentro entre Simón y Pedro, señalando que Lucas fue el responsable de la conexión entre Simón y Felipe ${ }^{11}$.

Oscar Cullmman argumentó12 que los v. 14-17 contenían una tradición posterior a la de Felipe-Simón. Esa fuente describía la intervención de Pedro y Juan, quienes, como representantes de los Doce, fueron enviados a hacerse cargo de una misión "helenista" en Samaría. Por su parte, Ernst Haenchen ${ }^{13}$ afirmó que las historias de Felipe y Simón estaban originalmente separadas, pero fueron unidas por Lucas para ilustrar la superioridad del Espíritu y el éxito de Felipe sobre Simón. Según este autor, la fuente original de Lucas contenía también un episodio de la oferta de dinero de Simón a Felipe y la introducción de Pedro en 8,14-25 sería una construcción lucana. Por su lado, Hans Conzelmann discernió tres estratos de material tradicional en Hch 8,4-25: una historia sobre el éxito de Felipe en Samaría; un relato amalgamado acerca de Felipe y Simón; y una tradición que combina una historia de Felipe con una tradición sobre Pedro y Juan. Lucas habría heredado este tercer y último estrato ${ }^{14}$.

Gerhard Schneider considera que Lucas tenía inicialmente dos tradiciones -la historia de Felipe en 8,4-12 y el bautismo de un prosélito etíope 8,26-40- que amplió por medio de una interpolación ${ }^{15}$ que detallaba las actividades de los apóstoles Pedro-Juan, mientras que la figura de Simón proporcionaba el vínculo entre 8,4-13 y 8,14-25. Schneider sospecha que Lucas eligió las tradiciones de Felipe de una colección más amplia de historias similares, a la cual se agregó una crónica de Simón que constaba de dos unidades distintas de la tradición; a saber, una que describía su conversión y bautismo, y una segunda acerca de su oferta pecuniaria para adquirir el derecho de conferir el Espíritu Santo. Dado este escenario, Schneider supo-

\footnotetext{
11 BAUERFEIND, Otto, Die Apostelgeschichte (=ThHK 5), J.C. Hinrichs, Leipzig 1939, 124.

12 Cullmann, Oscar, "Samarien und die Anfange der christlichen Mission. Wer sind die A $\Lambda \Lambda$ OI von Joh. 4,38?", en FrÖHLICH, Karlfried (Hrsg.), Oscar Cullmann zum 65. Geburtstag. Vorträge und Aufsätze 1925-1962, J.C.B. Mohr (Paul Siebeck) - Zwingli, Tübingen - Zürich 1966, 232-240.

13 HaEnChen, Die Apostelgeschichte, 258.

14 Conzelmann, Hans, Die Apostelgeschichte (=HNT 7), J.C.B. Mohr (Paul Siebeck), Tübingen ${ }^{2} 1972,61$.

15 SChNEIDER, Gerhard, Die Apostelgeschichte, Teil 1. Einleitung, Kommentar zu Kap. 1,1-8,40; Herder, Freiburg 1980, 484: “...ist durch eine Einschaltung über das Wirken der Apostel Petrus und Johannes in Samaria (8:4-25) erweitert...”.
} 
ne que los v. 14-17 son pura invención lucana para hilvanar y entrelazar dos tradiciones iniciales. También, puesto que Lucas añadió la visita de Pedro y Juan, es posible que conociera dos misiones independientes en Samaría y optara por apoyar a la de Jerusalén.

Gerd Lüdemann proporciona un análisis estadístico del vocabulario y de la sintaxis de Hch 8,4-25 y concluye que lingüísticamente toda la sección es claramente lucana ${ }^{16}$. Incluso califica la escena de la efusión del Espíritu (14-17) como "redaccional, tanto en lenguaje como en contenido" (101). Identificando a Lucas como el autor de las secciones 8,14-17 y 8,18-24, Lüdemann disiente de las conclusiones de Wellhausen, Haenchen, Conzelmann y Schneider, quienes postularon una tradición anterior detrás de los versículos 18-24. Lüdemann argumenta que la fuente de Lucas reflejaba un estrato de material tradicional que detallaba tanto el éxito misionero de Felipe, como el conflicto entre Felipe y Simón proveniente de círculos helenistas (5-13). De forma coetánea al autor anterior, Dietrich-Alex Koch ${ }^{17}$ aboga por una escena tradicional basada en PedroSimón para 8,18-24. Identifica tres elementos pre-lucanos en 8,4-25: (1) un informe misceláneo y general sobre la actividad misionera de Felipe en Samaría; (2) una historia sobre la actividad y culto de Simón en Samaría; y, (3) la representación de un conflicto entre Pedro y Simón el Mago. Al presentar la narración de Pedro-Simón en la sección de Felipe (8,911.13), Lucas pudo elaborar su relato sobre la actividad misionera de Felipe, para la cual no tenía "material concreto". Koch sugirió que la conclusión incómoda de la confrontación entre Pedro y Simón en 8,22-24 es lucana. Aunque D.-A. Koch adujo evidencias exegéticas para apoyar los dos primeros elementos, sin embargo no proporcionó ningún análisis para sustentar su tercer elemento pre-lucano, al margen de una pretensión para detectar la tradición oral detrás de la escena.

En su comentario clásico, Charles Barrett afirma que aunque Hch 8,4-25 constituye una sola historia, pero es posible que Lucas haya usado cuatro fuentes para su composición: la actividad de Felipe en la ciudad de Samaría (5-8); una continuación de la labor de Felipe con la conversión de los antiguos seguidores de Simón el Mago y Simón mismo (9-13); un pasaje editorial que describía la intervención de Pedro y Juan (14-17) y la reprensión de Pedro a Simón (18-24) ${ }^{18}$. Por su parte, el v. 25 constituiría

16 LÜDEmann, Das frühe Christentum, 99-106.

17 KосH, Dietrich-Alex, "Geistbesitz, Geistverleihung und Wundermacht. Erwagungen zur Tradition und zur lukanischen Redaktion in Act 8,5-25", en ZNW 77 (1986) 64-82, aquí 67-80.

18 BARrett, A Critical and Exegetical Commentary, 398s. 
una conclusión editorial. Barrett sugirió un argumento literario para afirmar que Lucas había fusionado una tradición de Felipe con una tradición de Simón, ya que Simón y Felipe no se mencionan realmente juntos hasta 8,13. Sin embargo, Barrett descartó la propuesta de Schneider de que Lucas hubiera tenido a su disposición dos tradiciones distintas de Simón: parece más probable que Lucas dispusiera de una serie de fragmentos de información acerca de Simón, y no que hubieran existido dos narraciones claramente contrastantes, una que describiera su conversión y servicio

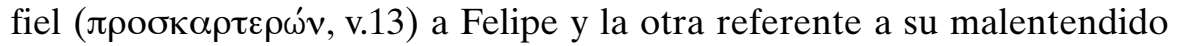
mágico de la verdad cristiana y severa reprimenda de Pedro.

Todas estas reconstrucciones reconocen la existencia de una cesura significativa del relato en 8,14. Varios autores consideran que Lucas, precisamente en ese versículo, ha dejado de seguir a su fuente (Loisy, Haenchen, Lüdemann), otros que comenzó siguiendo de cerca su fuente (Koch, Waitz), o aún otros que Lucas (Bauernfeind, Barrett) o su tradición (Conzelmann) ha fusionado dos o más fuentes ${ }^{19}$. Con la excepción de Lüdemann, todos los eruditos anteriores sostienen de una manera u otra que Felipe no estaba originalmente asociado con Simón. Hay dos tipos de argumentos en contra de esta vinculación. Quienes consideran que la fuente relataba primariamente una relación entre Pedro y Simón, piensan que Lucas es responsable del vínculo literario entre Felipe y Simón. El segundo argumento es un argumento histórico que afirma que Felipe se dirigió a los samaritanos, el grupo religioso de "semi-judíos", encontrado, por ejemplo, en la parábola del buen samaritano, mientras que Simón era activo entre los "Samarians", los gentiles que vivían en Samaría $^{20}$. Por lo tanto, se concluye que la misión de Felipe no lo habría puesto en contacto con Simón. Este segundo punto de vista se basa en argumentos que son difíciles de establecer con certeza. Por desgracia no conocemos lo suficiente acerca de las circunstancias históricas que rodearon la actividad y la enseñanza de Simón, como para poder superar estos problemas históricos.

En conclusión y al margen de la dificultad de poder optar por una de las tesis propuestas ${ }^{21}$, considero que Lucas ha reelaborado aquí tradiciones sobre la misión samaritana del cristianismo primitivo por parte de

\footnotetext{
19 BARRetT, "Light on the Holy Spirit", 284; LÜDEMAnN, Das frühe Christentum, 104s.

20 Jervell, Die Apostelgeschichte 267, rechaza que se pueda decidir si Felipe evangelizó entre la población pagana o entre la comunidad samaritana.

21 Muchos autores consideran que es difícil optar entre tantas propuestas y detalles, cf. Bock, Darrell L., Acts (=Baker Exegetical Commentary on the New Testament), Baker Academic, Gran Rapids, Michigan 2007, 322.
} 
los helenistas, en la que Felipe jugó un papel prominente, una tradición personal vinculada a Simón el Mago, posiblemente también una tradición de la aparición/llegada de Pedro (y Juan) a Samaría. Es evidente que ha otorgado su propia impronta personal a nivel lingüístico y de contenido a la presentación actual del relato.

Esta compleja historia de la composición puede ayudar a una posible comprensión de la característica más llamativa y discutida del pasaje. Felipe predica a los samaritanos. Estos creen y son bautizados; pero no reciben el Espíritu Santo. Posteriormente, los apóstoles de Jerusalén, Pedro y Juan, visitan Samaría y completan el bautismo de Felipe, quienes oran e imponen las manos sobre los samaritanos para que reciban el Espíritu. ¿Por qué no recibieron el Espíritu en el momento del bautismo (cf. 2,38)? ¿Acaso Felipe no tenía la competencia necesaria para transmitir el Espíritu? Esto es tanto más sorprendente cuanto que según 8,16 el

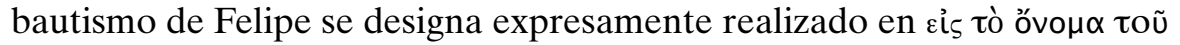
кupíov 'I confirmación mediante la imposición de manos un complemento necesario del bautismo? Todas estas cuestiones son pertinentes, siempre y cuando la recepción del Espíritu estuviera vinculada directamente al rito bautismal en la concepción lucana, pues de no ser así, el texto no presentaría ninguna anomalía bautismal.

\section{BAUTISMO Y RECEPCIÓN DEL ESPÍRITU 22}

Por motivos obvios no podemos abordar aquí la pneumatología lucana $^{23}$, sino sólo la cuestión de la relación de la recepción del Espíritu y

\footnotetext{
22 La literatura es amplia: BRown, Schuyler, “'Water Baptism' and 'Spirit Baptism' in Luke-Acts", en ATR 59 (1977) 135-51; Christiansen, Ellen Juhl, "Taufe als Initiation in der Apostelgeschichte", en ST 40 (1986) 55-79; DAS, A. Andrew, "Acts 8: Water, Baptism, and the Spirit", en Concordia J. 19 (1993) 108-34; DunN, James D.G., Baptism in the Holy Spirit: A Re-Examination of the New Testament Teaching on the Gift of the Spirit in Relation to Pentecostalism Today, SCM Press - Westminster Press, London - Philadelphia 1970, 55-72; 90-102; FEE, Gordon D., "Baptism in the Holy Spirit: The Issue of Separability and Subsequence", en Pneuma 1 (1985) 87-99; FrankLIN, Lloyd David, "Spirit-Baptism: Pneumatological Continuance", en RevExp 94 (1997) 15-30; HARTMAN, Lars, 'Into the Name of the Lord Jesus'. Baptism in the Early Church (=SNTW), T. \& T. Clark, Edinburgh 1997, 127-145; O’Toole, Robert F., "Christian Baptism in Luke", en RevRel 39 (1980) 855-866; Spencer, F. Scott, The Portrait of Philip in Acts: A Study of Roles and Relations (=JSNTSup 67), JSOT Press, Sheffield 1992, 211-241.

23 Sobre la literatura referente al Espíritu en la iniciación cristiana según Lc y Hch, cf. MCCollough, David John, Ritual water, ritual spirit: an analysis of the timing, mecha-
} 
el bautismo. Esta vinculación aparece por primera vez en el discurso de

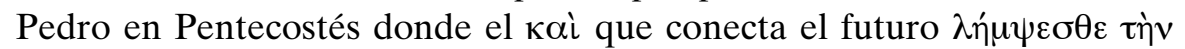

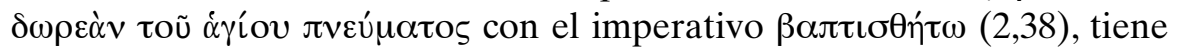
un significado consecutivo: "Pedro les respondió: 'Arrepentíos y bautizaos cada uno de vosotros en el nombre de Jesucristo, para que queden perdonados vuestros pecados. Entonces recibiréis el don del Espíritu Santo"" (Hch 2,38). Estas instrucciones de Pedro han sido consideradas paradigmáticas para la teología bautismal del libro de Hechos ${ }^{24}$. La recepción del Espíritu sería, pues, resultado del bautismo, aunque el relato no menciona posteriormente que los bautizados recibieran dicho Espíritu, tal vez porque Lucas lo consideraba implícito en el "bautizarse" 25.

Más reveladores son los tres episodios en Hch 8; 10 y 19, donde se establece una clara cesura entre el bautismo y la recepción del Espíritu. Paradójicamente, sin embargo, muestran que, según Lucas, la recepción del Espíritu forma parte fundamental del bautismo. Así, la perícopa de Samaría constata una carencia de quienes habían sido bautizados: "toda-

nism, and manifestation of spirit-reception in Luke-Acts. PhD thesis, Middlesex University - London School of Theology 2014, 4-37; Menzies, Robert P., Empowered for Witness. The Spirit in Luke-Acts (=JPTSup 6), JSOT Press, Sheffield 1994, 202-225; Hur, Ju, A Dynamic Reading of the Holy Spirit in Luke-Acts (=JSNTS 211), T\&T Clark International, London 2001.

${ }^{24}$ Es representativo el análisis de Max Turner de Hch 2,38 como normativo, Power from on High. The Spirit in Israel's Restoration and Witness in Luke-Acts (=JPTSup 9), JSOT Press, Sheffield 1996, 397-98; TuRner, Max, "The Work of the Holy Spirit in LukeActs", en WW 23 (2003) 146-153. En contra, cf. GreEN, Joel B., "From 'John's Baptism' to 'Baptism in the Name of the Lord Jesus': The Significance of Baptism in Luke-Acts", en: Porter, Stanley E. - Cross, Anthony R. (eds.), Baptism, the New Testament and the Church Historical and Contemporary Studies in Honour of R.E.O. White (=JSNTS 171), Sheffield Academic Press, Sheffield 1999, 157-172. Según KeEner, Craig S., Acts. An Exegetical Commentary, II, Baker Academic, Grand Rapids 2012: "Instead of reading his apparently ideal theological paradigm (2:38) into the narrative evidence, Luke allows for a diversity of pneumatic experience $(8: 12-17 ; 10: 44-48 ; 19: 5-6)$ and presumably invites his audience to show the same courtesy" (681); Idem,. Gift and Giver. The Holy Spirit for Today, Baker, Grand Rapids 2001, 162.

25 Una presentación del status questionis de la relación entre el bautismo de agua y la recepción del Espíritu se encuentra en Lyons, Thomas, "Praxis, Phenomena, and Spirit Reception in Luke-Acts: A Study of Shared Elements in Luke's Corporate Baptism of the Holy Spirit Accounts", en The Asbury Journal 71 (2016) 109-127, 112-114: "One common understanding of the relationship between water baptism and the Holy Spirit is that water baptism necessarily precedes Spirit reception in a sequential chronological manner, as laid out by Peter in Acts 2:38... Another representative position held regarding the relationship between water baptism and Spirit reception is that of G.W.H. Lampe, which collapses water baptism and Spirit reception into a single coterminous event... Finally, a third position allows for water baptism to normally precede Spirit reception without it becoming normative". 
vía" no había llegado sobre ninguno de ellos el Espíritu Santo (v. 16). Por consiguiente, el don del Espíritu no se encuentra implícito en el bautismo, ni hay duda de que Lucas considera "normativo" la recepción del Espíritu por parte de los bautizados. La norma tiene un peso tal que la desviación fáctica, tan pronto como se constata, desencadena una acción inmediata para remediar dicha situación.

El episodio de Cornelio testimonia la misma necesidad normativa, simplemente que aquí el don del Espíritu precede al bautismo. Tan pronto como la gente de Cornelio testimonia la recepción del Espíritu mediante el don de lenguas y la alabanza a Dios (10,44-47), Pedro organiza el bautismo de agua $(10,47 \mathrm{ss}$.). La razón de su bautismo no radica tanto en la recepción del Espíritu en ellos como tal, sino que esta es análoga a la de Pedro y sus compañeros: Quien es receptor del Espíritu, como lo fueron los primeros discípulos, tiene derecho a ser bautizado.

La narración del bautismo realizado por Pablo en Éfeso confirma que la combinación del bautismo y la recepción del Espíritu es la norma en la perspectiva lucana. Como en Samaría y Cesarea, tan pronto como se constata la deficiencia, se intenta subsanar lo antes posible. Las dos preguntas con las que Pablo diagnostica el problema, presuponen que en ciertas circunstancias los cristianos pueden haber sido bautizados sin recibir el Espíritu. El desarrollo del relato muestra, sin embargo, que esta posibilidad no se corresponde con la norma, aunque de facto sucede. En Éfeso, a diferencia de Samaría, no sólo se subsana la carencia del don del Espíritu, sino que también se les bautiza por segunda vez. Este segundo bautismo no habría ocurrido, si los discípulos hubieran sido previamente bautizados "en el nombre del Señor Jesús" en lugar de recibir "el bautismo de Juan" (19,3). La norma supuesta por Lucas es, pues, aún más precisa: el creyente tiene derecho no simplemente al bautismo y al Espíritu Santo, sino al bautismo cristiano y al Espíritu Santo.

Lo que de forma velada se encuentra en la invitación al bautismo en la perícopa de Pentecostés, se confirma, a su modo, a través de las narraciones bautismales de Hch 8, 10 y 19, a saber, que según la visión lucana el don de Espíritu Santo está en estrecha conexión con el bautismo. Además, permiten precisar con mayor detalle lo que el tenor de la redacción en 2,38 deja en el aire: En primer lugar, el Espíritu no se transmite automáticamente mediante el rito del bautismo, pues de otro modo los cristianos samaritanos lo hubieran recibido sin necesidad de los apóstoles $(8,16)$. En segundo lugar, la norma adoptada por Lucas requiere la secuencia más rápida posible del bautismo y la recepción del Espíritu, pues de lo contrario el retra- 
so no pudiera ser considerado una anomalía $(8,16 ; 19,2-3)$. En tercer lugar, dentro del complejo suceso de la conversión y la iniciación, el bautismo precede y a él está subordinada y asociada la concesión del Espíritu. El arrepentimiento/conversión y la fe no se pierden totalmente de vista, pero juegan un papel menor $(2,38 ; 11,17 ; 19,2)$.

\section{El BAUTISMo Y LA IMPOSICIÓN DE MANOS 26}

Al igual que la primera efusión fundacional del Espíritu en Hechos $(2,1-4$, cf. 1,14$)$, el "Pentecostés samaritano" tiene lugar en un contexto de oración $^{27}$. El texto que nos ocupa pudiera hacernos pensar que la concesión del Espíritu no está vinculada directamente al bautismo y sí a la oración de los apóstoles $(8,15)^{28}$ y al rito de la imposición de manos $(8,17$ 19): el Espíritu es dado en respuesta a la oración de los apóstoles y mediante la imposición de sus manos. Igualmente, en el episodio de Éfeso, la efusión del Espíritu Santo viene precedida por la imposición de manos de Pablo (Hch 19,5-6), aunque ello no excluye que esta aconteciera de forma simultánea al rito del agua e incluso se presupusiera como componente normal del mismo ${ }^{29}$.

Los exégetas, sin embargo, no consideran que la estrecha interrelación del bautismo y el Espíritu se vea afectada por la inserción de la imposición de manos o la oración entre ambos ritos. Los diferentes ritos no compiten en la visión lucana, sino que, como muestra el episodio de Éfeso, se pueden combinar entre sí y al mismo tiempo se relacionan con el don del Espíritu.

${ }^{26}$ AdLER, N., Taufe und Handauflegung. Eine exegetisch-theologische Untersuchung, Aschendorff, Münster 1951, 71-76; 93-108; WhITEHouse, Michael Patrick, Manus Impositio: The Initiatory Rite of Handlaying In The Churches of Early Western Christianity, PhD Dissertation, Notre Dame, Indiana 2008, 66-79; Oulton, J.E.L., "The Holy Spirit, Baptism, and Laying on of Hands", en ExpTim 66 (1955) 236-240; BEASLEY-MurRay, Baptism 122-125.

27 HoLmÅs, Geir Otto, Prayer and Vindication in Luke-Acts. The Theme of Prayer within the Context of the Legitimating and Edifying Objective of the Lukan Narrative (=LNTS 433), T\&T Clark International, London - New York 2011, 194-199.

28 Es llamativo que la versión lucana del bautismo de Jesús inserte la oración de Jesús entre el bautismo y el descenso del Espíritu (Lc 3,21s). MenZies, Empowered, 121.134.177.187, considera que la recepción del ES está asociada con la oración y no con el bautismo de agua. Por el contrario, para Turner, Power from on high, 340, 402, ésta no está vinculada tanto a la oración, cuanto a la iniciación de la conversión.

${ }^{29}$ Para AdLER, Taufe, 107, la imposición de manos no constituía una ceremonia perteneciente al bautismo. 
No obstante, respecto a la transmisión del Espíritu existen dos diferencias importantes entre ambos ritos: Mientras que la imposición de manos conduce indefectiblemente a su objetivo, sin embargo la recepción del Espíritu no acontece, con relativa frecuencia, en el bautismo. Por otra parte, la conexión entre el bautismo y la recepción del Espíritu aparece reiteradamente y se presenta como una norma, mientras que no existe una normatividad de la imposición de manos. Sin que esta última debiera estar contenida en la noción del bautismo, sería concebible que Lucas no viera la necesidad de mencionar la trasmisión del Espíritu, que según su concepción sigue por regla general al bautismo y, de igual modo, conociera la relación evidente con la imposición de manos, la cual puede dejar sin mencionar, donde la recepción del Espíritu no planteaba ningún problema.

¿La imposición de manos constituiría un rito sui generis, que sólo aparece con el bautismo cuando la trasmisión del Espíritu no acontece por otros medios o es un componente necesario del ritual de iniciación cristiana? Difícilmente se puede responder a esta cuestión, pues solo dos relatos de bautismos $(9,12)$ hablan de una imposición de manos, que tiene como objetivo claramente la transmisión del Espíritu y precisamente estos dos textos tienen que lidiar con el problema de la ausencia inicial del Espíritu. Por lo tanto, las probabilidades se encuentran en ambos lados de la balanza: $\mathrm{O}$ bien la imposición de manos está tan estrechamente ligada a la concesión del Espíritu que Lucas no necesita mencionarla, como sucede en la conclusión de la perícopa de Pentecostés. O considera la necesidad de la imposición de manos, un rito originario en otro contexto, sólo en casos excepcionales después del bautismo, cuando la recepción del Espíritu es obstaculizada por ciertos elementos, de tal forma que se requieren medidas adicionales, tal como la oración, para propiciar el don del Espíritu ${ }^{30}$.

\section{SEPARACIÓN DEL BAUTISMO Y LA RECEPCIÓN DEL ESPÍRITU}

El principio de la vinculación de la recepción del Espíritu con el bautismo no se cumple en todos los casos, pues existen varios casos de

30 Según la tesis de McCollough, Ritual water, 165s., Hechos 8 proporciona la primera presentación de Lucas de los nuevos conversos recibiendo el Espíritu y mostrando los mecanismos utilizados que facilitan su efusión, la oración y la imposición de manos de individuos dotados de Espíritu. Lucas no afirma que este procedimiento fuera excepcional ni estándar, simplemente presentó una solución al problema. 
desviación del modelo. ¿Están justificadas estas excepciones desde el punto de vista lucano?

En el episodio de Éfeso, esta pregunta puede ser contestada de modo afirmativo. Sin embargo, la anomalía no radica en el ritual con el que concluye la historia. Al contrario, este está en total conformidad con la norma lucana, como corrobora Pablo en el diálogo precedente: “'¿Habéis recibido el Espíritu Santo al abrazar la fe?'. Ellos respondieron: 'Ni siquiera hemos oído hablar de que exista un Espíritu Santo'. Él les dijo: 'Pues ¿qué bautismo habéis recibido?'” (19,2-3). Así pues, los doce discípulos, cuando llegaron a la fe, fueron bautizados sin recibir el Espíritu. Lucas explica esta anomalía con el tipo de bautismo recibido: fueron bautizados solamente en el "bautismo de Juan" $(19,3)$, un bautismo que no estaba asociado con la concesión del Espíritu. Un cristianismo de origen deficitario y procedencia oscura se integra en la comunidad apostólica de la Iglesia, y el bautismo de Juan es reemplazado por el bautismo en el nombre de Jesús. No obstante, surge una incoherencia en el contexto de la narración en referencia a Apolo: ¿por qué Apolo, "que sólo conocía el bautismo de Juan" $(18,25)$, no fue bautizado en el nombre del Señor Jesús? Que Apolo fuera ya portador del Espíritu sería una razón obvia, pero no la única concebible. Lucas no proporciona una respuesta a tal cuestión ${ }^{31}$.

Para explicar la recepción tardía del Espíritu en Samaría, la investigación ha considerado diversas alternativas. La forma tradicional de explicar el problema consistía en aceptar el contenido de v. 4-13 y cuestionar las afirmaciones de v. 14-24: los samaritanos se convirtieron en cristianos con el bautismo, por lo tanto las afirmaciones de v. 14-17 no pueden significar lo que parecen indicar, dando lugar a diversas interpretaciones. Por su parte, los pentecostales se refieren regularmente a Hechos 8 como el ejemplo más obvio del paradigma pentecostal clási$\mathrm{co}^{32}$, el caso más claro de la doctrina de la "subsecuencia", es decir, primero se accede a la salvación por la fe y el compromiso con Cristo (marcado por el bautismo de arrepentimiento) y posteriormente se recibe el

31 Barrett, C.K., "Apollos and the Twelve Disciples of Ephesus", en Weinrich, William C. (ed.), The New Testament Age: Essays in Honor of Bo Reicke, I, Mercer University, Macon, GA 1984, 29-39.

32 Menzies, Robert B., The Development of Early Christian Pneumatology with Special Reference to Luke-Acts, Sheffield Academic Press, Sheffield 1991; idem, Empowered for Witness The Spirit in Luke-Acts, Sheffield Academic Press, Sheffield 1994; Penney, John Michael, The Missionary Emphasis of Lukan Pneumatology, Sheffield Academic Press, Sheffield 1997. Una posición más abierta Shelton, James B., Mighty in Word and Deed The Role of the Holy Spirit in Luke-Acts, Hendrickson, Peabody 1991. 
Espíritu. Por tanto, se trata de una pneumatología en dos etapas, según la cual los samaritanos reciben inicialmente el Espíritu que mora en su interior para la salvación, luego, mediante la imposición de manos de los apóstoles, reciben el "bautismo en el Espíritu Santo". En el ámbito católico se ha usado tradicionalmente este texto como fundamento del sacramento de la confirmación.

Expondremos a continuación una serie de explicaciones y razones por las cuales se decía que la conversión de los samaritanos era imperfecta antes de la llegada de los apóstoles, para lo cual nos basaremos en las obras de J.D.G. Dunn ${ }^{33}$ y M. Turner ${ }^{34}$.

\section{Los samaritanos ya habían recibido el Espíritu y los v. 14-17 hacen referencia a su manifestación carismática}

Si los samaritanos verdaderamente creen en Jesús, ¿por qué Lucas hace la separación de la conversión/bautismo y la recepción del Espíritu? G.R. Beasley-Murray argumenta que no hay separación entre conversión y recepción del Espíritu. Lucas consideraba a estos cristianos "no sin el Espíritu, sino sin los dones espirituales que caracterizaban la vida común de las comunidades cristianas"35. Según este autor, el fruto del Espíritu, "la gran alegría" de Hch 8,8, implica que los samaritanos recibieron el Espíritu en el momento del bautismo, y el uso dispar de $\pi v \varepsilon \tilde{\mu \alpha} \alpha \ddot{\gamma} \gamma$ (sin artículo) en Hch 8,15-16 sugiere que los apóstoles impartieron dones espirituales, no el Espíritu mismo. Ninguno de estos argumentos es convincente ${ }^{36}$. La gran alegría de Hch 8,8 se debe a las sanaciones y exorcismos realizados por Felipe, pero no implica necesariamente la posesión del Espíritu. Tampoco puede hacerse una distinción clara entre tò $\pi v \varepsilon \tilde{u} \mu \alpha$ tò $\ddot{\alpha} \gamma$ เov y $\pi v \varepsilon \tilde{u} \mu \alpha \ddot{\alpha} \gamma\left\llcorner o v\right.$, pues son títulos equivalentes ${ }^{37}$. Sin

\footnotetext{
33 Dunn, Baptism, 56-63.

34 Turner, Power from on High, 360ss.

35 Beasley-Murray, Baptism, 119. Semejante opinión expresa Fergusson, Baptism 171: "It may be that Luke's wording here implies that the Samaritans received the indwelling presence of the Spirit when they were baptized into the name of Jesus, but no special or external manifestations of the working of the Spirit were present... It may be that the delay in God's giving special manifestations of the Spirit to the Samaritans until apostolic representative arrived from Jerusalem was to emphasize the significance of the expansion of the gospel to Samaria and to confirm the unity of Jews and Samaritans in the church".

36 Para una crítica cf. Dunn, Baptism, 70; TuRner, Power from on High, 369; HayA Prats, Gonzalo, Impulsados por el Espíritu. El Espíritu Santo en los Hechos de los Apóstoles, Secretariado Trinatario, Salamanca 2011, 30-54.
} 
embargo, la objeción decisiva contra la tesis de Beasley-Murray es la afirmación explícita de Lucas en el v. 16: el Espíritu "todavía no había descendido sobre ninguno de ellos".

\section{Hch 8,14-17 indica una segunda recepción del Espíritu}

Esta sugerencia tampoco se puede sostener ante la afirmación inequívoca de Lucas con la que finalizamos el párrafo anterior. Los paralelismos entre 8,5-13 y 2,41-47, y los milagros y alegrías entre los samaritanos

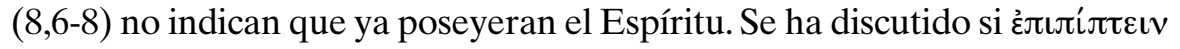

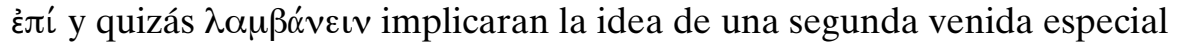
del Espíritu. Pero cuando comparamos el lenguaje de Lucas de nuestro texto con su descripción de la venida del Espíritu en otros pasajes, es evidente, que Lucas no conoce ninguna llegada anterior del Espíritu que la que

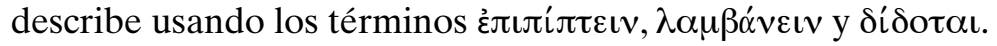

Tal vez algunos estudiosos estén dispuestos a decir que la presentación de Lucas era tan superficial que sólo le interesaban las funciones externas y visibles del Espíritu; que la primera venida, aunque fuera la que constituía a la persona como cristiana, tenía tan poca relevancia para él que nunca la mencionó, mientras que la verdadera e importante efusión del Espíritu era la que resultaba en una exhibición de dones espirituales ${ }^{38}$.

\section{El don del Espíritu se transmite exclusivamente mediante la impo- sición de manos}

Otra línea de investigación dirigió desde la antigüedad sus miradas hacia el agente ritual, Felipe, a quien a menudo se le consideró que sólo estaba cualificado para bautizar con agua -es decir, que era un mero diácono-, y por consiguiente no podía conferir el Espíritu Santo a los samaritanos. Esta opinión ya fue rebatida por Amonio (Catena en Hechos 8,15-17; 138.8), quien argumenta que, aunque las Escrituras no lo mencio-

37 Véase el apéndice dedicado al uso o carencia del artículo referido al Espíritu Santo en Haya Prats, Impulsados, 335-347.

38 Poco convincente la opinión de Haya Prats, Impulsados, 202, "este texto no niega que en el bautismo administrado por Felipe hubieran recibido los samaritanos el Espíritu Santo en forma interior, invisible, santificadora. Hechos no habla nunca de tal presencia del Espíritu, y por consiguiente tampoco la niega". 
nan explícitamente, Felipe participó de forma activa, junto con Juan y Pedro, a la hora de orar e imponer las manos sobre los samaritanos para que recibieran el Espíritu Santo ${ }^{39}$. Al margen de esta explicación sin apoyo textual, la interpretación de Felipe como diácono es anacrónica, pues no se usa el término en el libro de los Hechos, al tiempo que se presenta a Felipe como uno de los Siete helenistas que estaba lleno de Espíritu y sabiduría $(6,3)$.

Según otros exegetas, Lucas consideraba la mediación del Espíritu como un privilegio exclusivo de los apóstoles basándose en la observación de Simón el Mago de que el Espíritu se concedía "mediante la imposición de manos de los apóstoles" $(8,18)$, por lo que el "evangelizador", proveniente del círculo de los Siete helenistas, difícilmente podría haber gozado de tal prerrogativa $(21,8 ; 6,5)$. En contra de esta propuesta, sin embargo, en ningún lugar se sugiere que los apóstoles constituyeran el único medio por el que se otorgaba el Espíritu Santo y la frase de Simón no está formulada, en modo alguno, de forma excluyente, como que los evangelistas, que no son apóstoles, no son capaces de transmitir el Espíritu Santo por medio de la imposición de manos. Además, según el texto de 8,39 , de acuerdo con la lectura de muchos manuscritos, el eunuco etíope recibirá el Espíritu Santo al emerger del agua que sigue al bautismo llevado a cabo por Felipe: "cuando subió del agua, el Espíritu Santo descendió sobre el eunuco, y el ángel del Señor arrebató a Felipe". Igualmente, Ananías, a quien Lucas no otorga ningún título eclesiástico, impone sus manos sobre Saulo y este será sanado y lleno del Espíritu Santo $(9,17)$, sin que se mencione la intervención de algún apóstol de Jerusalén. El mismo Pablo $(19,6)$, sin ser apóstol en la concepción lucana, practicó la imposición de manos con el objeto de transmitir el Espíritu. En este sentido, Felipe se encuentra al mismo nivel de Pablo, ya que incluso los Siete habían sido instituidos mediante la imposición de manos de los apóstoles de Jerusalén $(6,6)$.

39 “¿Por qué Felipe no logró que sus bautizados participasen del Espíritu Santo? Por aquel que tiene que defender la gracia de Dios, porque aun si al principio nadie recibió el Espíritu Santo cuando Felipe bautizó a los de Samaria, ciertamente después, después de que Juan y Pedro oraron, él [Felipe] confirió el Espíritu Santo mediante la imposición de sus manos a los que habían sido bautizados.... [La Escritura] no dice que sólo por medio de Pedro y Juan, sino que hablando sin distinción, incluye también a Felipe" [cf. Hechos 8,17]. Catena en Hechos 8,15-17; 137,1 - 138,23), tomado de HorniK, Heidi J. - PARsons, Mikeal C., The Acts of the Apostles Through the Centuries (Wiley Blackwell Bible Commentaries), John Wiley, Chichester, West Sussex - Malden, MA 2017, 101s. 


\section{Lucas ha separado lo que de hecho estaba unido}

¿Ha creado el mismo Lucas la dificultad al expandir una historia referente a Felipe y Simón, en la que los samaritanos recibían el Espíritu por medio del ministerio de Felipe, y en el cual Pedro y Juan originalmente no aparecían? Se ha argumentado que la separación del don del Espíritu del rito bautismal en Hch 8,4-25 no representa una tradición históricamente fiable; más bien, el texto problemático es resultado de la modificación lucana del material de su(s) fuente(s). Se afirma que Lucas, al combinar dos fuentes originariamente independientes o embellecer una historia de la tradición ligada al ministerio de Felipe en Samaría (que incluía la conversión de Simón) con material existente referente a Pedro y Juan, separó el don del Espíritu del rito bautismal y dividió así lo que en realidad formaba una unidad indisoluble. Por tanto, desde una perspectiva de crítica de las fuentes (cf. supra II.2), la narración del episodio samaritano es una torpe redacción lucana de sus fuentes previas. Esta actividad editorial, se nos dice, fue motivada por el deseo de vincular la nueva comunidad de Samaría a Jerusalén y resaltar la autoridad de los apóstoles.

\section{Dios en su soberanía retenía el Espíritu de los cristianos}

Otros autores han tratado de rebajar la tensión al describir el curso de los acontecimientos narrados en Hch 8,4-25 como una excepción única requerida por un nuevo y decisivo punto de inflexión en la misión de la Iglesia: el Espíritu fue retenido hasta la venida de los apóstoles de Jerusalén con el fin de demostrar a los samaritanos que realmente se habían convertido en miembros de la Iglesia, en comunión con los "pilares originales" jerosolimitanos. Sin embargo, este punto de vista se enfrenta a serias objeciones. En primer lugar, hay pocas razones para suponer que este caso representa una excepción única, ya sea a nivel histórico o para Lucas. Nada en el texto apoya tal punto de vista. En segundo lugar, es altamente improbable que los samaritanos necesitaran más seguridad acerca de su incorporación a la Iglesia después del bautismo. Además, la garantía de integrarse en la Iglesia (así como la realidad misma) no depende del contacto con los representantes de Jerusalén (Hch 8,26-39; 9,17-18; 18,24-19,7), ni de su concesión del Espíritu a los 
recién convertidos (Hch 11,22-24). Sin embargo, aunque esta teoría sea aceptada, el "problema" planteado por el texto no viene erradicado.

La referencia al significado histórico eclesial y de la historia de la salvación de la misión samaritana es ciertamente la más adecuada para la narración lucana ${ }^{40}$. Aunque Lucas no menciona expresamente las intenciones originales de los delegados jerosolimitanos, su envío tendría como objetivo encontrar la aprobación de la misión de Samaría por parte de Jerusalén ${ }^{41}$. Sin embargo, las implicaciones de la política eclesial del incidente no explican el retraso de la recepción del Espíritu, pues se constata que en Cesarea, el Espíritu ya había descendido antes de que los de Jerusalén tuvieran noticia de los sucesos $(11,1)$. Si Lucas hubiera deseado ilustrar el problema de la integración eclesial de los samaritanos mediante el retraso de la recepción del Espíritu, entonces debería haber pospuesto el bautismo y la recepción del Espíritu hasta la llegada de los apóstoles. En consecuencia, la necesidad de la aceptación eclesial de una nueva empresa misionera no explica el abandono del principio de unidad entre el bautismo y la recepción del Espíritu.

\section{Los samaritanos todavía no eran cristianos}

La explicación de James Dunn sobre el fracaso de los samaritanos a la hora de recibir el Espíritu en la conversión inicial es que no entendieron la predicación de Felipe. Los samaritanos aún no habían alcanzado la fe cristiana auténtica debido a que Felipe no distinguió claramente su proclamación cristiana de las esperanzas samaritanas acerca de la llegada

40 Hur, A Dynamic Reading, 241: "The Spirit here, caused by God himself... in response to the apostles' prayer, can thus be characterized as apologetically verifying the Samaritan believers as God's true people regardless of their past ethnic or cultural hostility to Jews".

41 Como sostiene SPEnCER, The Portrait 212-220.241, los intentos por explicar el enigma a lo largo de tales líneas son engañosos. Como en otros lugares, la presentación de Lucas se rige por la preocupación de la continuidad del desarrollo divino del plan de salvación. Cuando los emisarios apostólicos aceptan y completan la misión innovadora de Felipe, esto demuestra el interés "histórico-salvífico" de Lucas en establecer la continuidad de cada nueva fase de la misión cristiana con el ministerio primitivo de Jesús -que culminó en Jerusalén- y con la comunidad de los discípulos de Jesús localizados en Jerusalén. La llegada del Espíritu en el marco de la oración apostólica es una finalización necesaria de la misión samaritana por parte de los principales representantes de la Iglesia madre y al mismo tiempo la marca decisiva de la aprobación de la admisión de los samaritanos en el pueblo mesiánico por parte de Dios. A petición de los apóstoles, la promesa del Padre, el don del Espíritu Santo, se otorga a los que están a los márgenes, confirmando su inclusión entre aquellos a quienes Dios "llama a él" (Hch 2,39). 
de Taheb (que introduciría un período de favor divino, un segundo Reino) y la "creencia" de los samaritanos estaba centrada en los signos de Felipe. Los samaritanos no eran realmente cristianos antes de recibir el Espíritu ${ }^{42}$. En apoyo de esta alegación formuló en su día los siguientes argumentos, aunque él mismo se ha distanciado en gran medida de su posición originaria ${ }^{43}$ :

(a) Para los samaritanos, la predicación de Felipe acerca de Cristo y del reino de Dios, desde un trasfondo de expectativa judía $(1,3.6 ; 19,8$; $20,25 ; 28,23.31)$, podría entenderse en términos de sus propias expectativas nacionalistas del Mesías, vinculadas a la figura mesiánica de Taheb que ellos esperaban ${ }^{44}$. Ellos aceptarían su predicación con entusiasmo (v. 8), habrían entendido el bautismo como el rito de entrada en el reino (v.12) y como símbolo de lealtad a Jesús, el Taheb. De forma no intencionada, la fe de los samaritanos estaba orientada de forma errónea.

(b) Los samaritanos respondieron a Felipe con muy poco discernimiento y profundidad (v. 9-11) y era un pueblo supersticioso. Su respuesta parece haber quedado atrapada en una ola de entusiasmo de masa. Su respuesta a Simón y a Felipe se describe con el concepto $\pi \rho \circ \varepsilon \tilde{\chi} \chi 0 v(8,6)$ ("prestar atención a"). Ello implica que la reacción de los samaritanos a Felipe fue por las mismas razones y de la misma calidad que su respuesta a Simón, que se centró en su capacidad para realizar signos. Por lo tanto, la aceptación de los samaritanos del bautismo fue motivada más por el instinto gregario de un movimiento popular de masas que por el auto-compromiso reflexivo.

(c) Dado que "creer" con el objeto en dativo suele significar asenti-

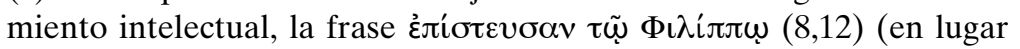

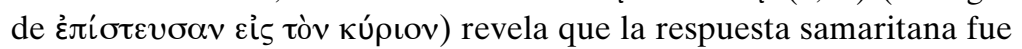
simplemente un asentimiento de la mente y no un reflejo de la fe genuina, ni implicaba una entrega confiada.

d) Lucas incluye el caso de Simón para demostrar que Simón y los samaritanos no se convirtieron en cristianos antes de 8,17. Aunque se dice que Simón creyó y fue bautizado, nunca se convirtió en miembro del pueblo de Dios. La respuesta de Pedro acerca de su comprensión del Espíritu indica que era un cristiano solo externamente. Su creen-

\footnotetext{
42 Dunn, Baptism 63-68.

43 "Baptism in the Spirit: A Response to Pentecostal Scholarship on Luke-Acts", en Journal of Pentecostal Theology 3 (1993) 3-27.

44 En ninguna parte Lucas insinúa que sus lectores asuman el conocimiento de la esperanza mesiánica del Taheb y posiblemente él mismo la desconociera. Además, Felipe expresamente predica el "nombre de Jesucristo" $(8,12)$.
} 
cia estaba centrada en los humanos, primero en Felipe (v. 13) y luego en Pedro (v. 24); no tenía ni idea de lo que era arrepentirse ante Dios y depositar su confianza en el Señor. Como la fe y el bautismo de Simón, la fe y el bautismo de los samaritanos no eran genuinos. Ellos pasaron a través de la forma de la fe y el bautismo, pero no experimentaron la realidad.

e) Lucas menciona la conversión de los samaritanos y de Simón en paralelo. Para Lucas, la posesión del Espíritu no se deduce del bautismo, sino que la autenticidad de la fe expresada en el bautismo se prueba y constata mediante la recepción del Espíritu. Tanto Simón como los otros samaritanos abandonan la magia, creen a Felipe y fueron bautizados. Pero la diferencia principal radica en que los samaritanos reciben el Espíritu, mientras que Simón recibe sólo una maldición, ya que los samaritanos han llegado a la fe genuina, mientras que Simón estaba interesado sólo en lo externo. La intención principal de Lucas es ilustrar la diferencia entre el cristiano, que recibe el Espíritu, y el no-cristiano.

f) La plena realización de la fe de los samaritanos fue retrasada por la animosidad racial entre judíos y samaritanos. Los samaritanos no estaban tan seguros de que fueran realmente aceptados en una comunidad cristiana compuesta de judíos y prosélitos hasta la llegada de los apóstoles de Jerusalén.

La hipótesis de Dunn ha sido ampliamente rebatida y sus argumentos son poco convincentes ${ }^{45}$, pues no hay nada que sugiera que los verbos "creer" y "ser bautizado" $(8,12.13)$ no tengan un sentido pleno. La carencia de los cristianos samaritanos es únicamente el don del Espíritu y solo a ello se orientan las medidas tomadas por los apóstoles llegados de Jerusalén.

\section{El don del Espíritu como donum-superadditum de habilitación para la misión}

La visión del don del Espíritu como donum-superadditum está en línea con el modelo pentecostal defendido por R. Stronstad y Menzies ${ }^{46}$.

45 Para una crítica de la tesis de Dunn, véase Turner, Power from on High, 363-367; MENZIES, Empowered, 208ss.

46 MenZies, Empowered, 211: "Luke viewed the gift of the Spirit received by the Samaritans (Acts 8.17) as of the same character as the Pentecostal gift; that is, as a prophetic endowment granted to the converted which enabled them to participate effectively in the mission of the church". 
"Para Lucas, el don del Espíritu tiene un propósito vocacional y capacita a los discípulos para el servicio... El don del Espíritu a los creyentes en Samaría demuestra que todos, incluso un grupo despreciado como los samaritanos, deben participar en la tarea misionera. Para esta responsabilidad común reciben el mismo equipamiento: el don vocacional del Espíritu" 47 . La promesa o el don del Espíritu se conciben como un conjunto diverso de bagajes del Espíritu al servicio de la misión.

En contra de esta propuesta, se constata que nada en el texto conecta específicamente el don del Espíritu con la misión. Tampoco se indica que los conversos samaritanos emprendieran la tarea de testificar a Cristo. La "imposición de manos" no significa necesariamente conferir una autorización para la tarea misionera, sino que el rito puede indicar en el período del Nuevo Testamento (1) la transferencia de poder, (2) la oración invocatoria (por ejemplo, para sanar, cf. Hch 28,8), y (3) la identificación, representación y transferencia legal o cuasi-legal de autoridad. La noción de "encargo" se basa en la tercera acepción. Pero la conversión de los samaritanos (8,16-19) no sugiere ninguna transferencia legal de autoridad o el "derecho de representación" de parte de los apóstoles. La respuesta de Simón el Mago confirma que la "imposición de manos", en este contexto, se relaciona con los paradigmas (1) y (2). En segundo lugar, es demasiado restrictivo suponer que el don del Espíritu es exclusivamente para la misión. En otras palabras, el don del Espíritu no era sólo para que la Iglesia captara nuevos adeptos, sino que también era para beneficio de quienes ya formaban parte de la comunidad cristiana. En tercer lugar, la visión del don del Espíritu como potenciador de la misión bien podría explicar por qué el Espíritu se otorga algún tiempo después de la fe inicial expresada en el bautismo, pero difícilmente explicaría el texto de 2,38-39, donde la recepción del Espíritu está estrechamente ligada a la conversión y al bautismo ${ }^{48}$.

47 Stronstad, Roger, The Charismatic Theology of St. Luke, Hendrickson Publishers, Peabody 1977, 64-65. En la segunda edición de su libro publicada por Baker Academic, Grand Rapids, MI 2012, 72, todavía es más clara su afirmación precedente: "For Luke, for the disciples, and earlier for Jesus (Luke 24:49; Acts 1:8; Luke 4:16-21), the gift of the Spirit has a vocational, commissioning, empowerment purpose".

48 Turner, Power from on High, 371-373. Hur, A Dynamic Reading, 240, n. 181. 


\section{Dos diferentes concepciones de conversión: la conversión judía y la conversión helenística-paulina}

En su tesis presentada en 198449 , M. Quesnel analiza la expresión cis

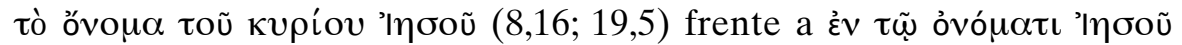

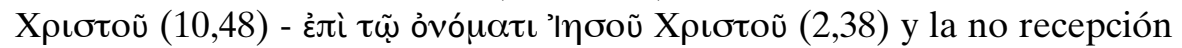
del Espíritu Santo, elementos que le llevaron a postular que la perícopa de Samaría y el bautismo de Éfeso presuponen el mismo rito bautismal, diferente a las narraciones petrinas que encontramos en Hch 2,38-39; 10,44-48. Por consiguiente, Hch reflejaría dos tipos diferentes de bautismos en uso históricamente en las primitivas comunidades cristianas: a) el

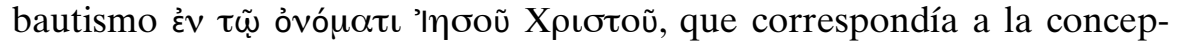
ción petrina y lucana del bautismo, el cual se desarrolla a partir del bautismo de Juan y representa una concepción judeocristiana. Este bautismo incluye el arrepentimiento, la conversión, el perdón de los pecados y la recepción del Espíritu Santo. b) El otro tipo de conversión es el rito helenístico-paulino del bautismo, realizado, entre otros, por Felipe cis tò

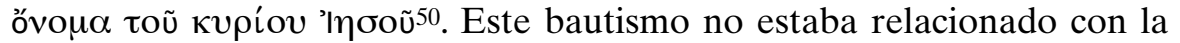
conversión, ni el perdón de los pecados, sino más bien expresaba la unión con el Señor Jesús ${ }^{51}$. Así mismo, la concesión del Espíritu Santo no sucedía de forma automática con el bautismo, sino gracias al rito independiente de la imposición de manos. Según Quesnel, la cautela de los helenistas y de Pablo ante el "Espíritu de profecía" propició que desarrollaran su rito centrado en la unión con la muerte de Jesús excluyendo la recepción del Espíritu. El bautismo de Felipe constituiría, pues, un ejemplo de bautismo paulino / helenístico. Aunque la visión lucana del bautismo es el bautismo judío que transmite el Espíritu Santo, el evangelista trató de preservar las dos diferentes tradiciones.

Esta propuesta también ha sido criticada. K. MacDonnell 52 argumenta que la reconstrucción de Quesnel es difícil de sostener. Es implausible sostener que la conversión del bautismo de Pablo / gentil no incluyera la conversión / el arrepentimiento en el bautismo de Saulo (Pablo).

\footnotetext{
${ }^{49}$ M. Quesnel, Baptisés 56-59.

50 Para una explicación detallada de esta fórmula bautismal cf. HARTMAn, Into de Name, 37-50.

51 QUESNEL, Baptisés dans L'Esprit, 87.

52 Véase el capítulo de McDonnell, Kilian, "Pentecostal Fire: Spirit-Baptism in Luke-Act", en McDonnell, Kilian - Montague, Jeorge T., Christian Initiation and Baptism in the Holy Spirit. Evidence from the first eight Centuries, Liturgical Press, Collegeville, Minnesota2 ${ }^{1994,33-34 . ~ O t r a s ~ c r i ́ t i c a s: ~ T u R n e r, ~ P o w e r ~ f r o m ~ o n ~ H i g h, ~} 369$.
} 
En 22,16, Ananías le dice a Saulo: "Levántate y recibe el bautismo y lava tus pecados invocando su nombre". Además, en la literatura paulina, no hay ninguna referencia a Pablo ni a ninguna persona que imponga las manos para el don inicial del Espíritu.

Tras exponer intentos explicativos de la problemática que abordamos, podemos concluir que ni la relación especial de los samaritanos con el judaísmo, ni la carente dignidad apostólica de Felipe, ni tampoco el requisito de una confirmación a posteriori de la misión de Felipe mediante la comunidad de Jerusalén pudieron constituir razones suficientes para que Lucas separara y retrasara la recepción del Espíritu. Parece probable que Lucas siguiera aquí una tradición que no coincidía con lo que él tenía en mente como modelo del bautismo de los primeros cristianos. Si fuera correcta esta hipótesis, entonces sería relevante para la historia de la praxis bautismal del cristianismo primitivo, pues se vislumbra aquí la posibilidad, en primer lugar, de poder rastrear un tipo "rudimentario" de bautismo, que no estaba vinculado a la recepción del Espíritu Santo y, en segundo lugar, un caso relativamente temprano de una aplicación práctica. Analicemos pues esta posibilidad.

\section{LA PRAXIS BAUTISMAL DE FELIPE}

Desde un punto de vista narrativo, Felipe (1) es uno de los expulsados de Jerusalén por la persecución en Judea y Samaría $(8,1)$; (2) no es un apóstol, ya que según la visión lucana, los apóstoles permanecen en Jerusalén $(8,1)$; y (3) va proclamando la palabra $(8,4)$. El contenido de su predicación, sin embargo, no se describe específicamente -Felipe no pertenece a los "oradores" en Hechos, sino que viene designado sumariamente con la formulación de "predicar a Cristo" $(8,5)$ o "anunciaba la buena nueva del reino de Dios y de Jesucristo" $(8,12)$. Como resultado de la aceptación de esta predicación "se bautizan" los samaritanos $(8,12)$ e, igualmente, Simón "recibió" el bautismo $(8,13)$. El relato hace presuponer la actividad bautismal de Felipe ${ }^{53}$, praxis que será mucho más clara en el bautismo del eunuco (8,36s.). Además, se muestra expresamente a Felipe como realizador de asombrosos signos y milagros $(8,6.13)^{54}$.

53 Aunque en 8,12.13.16, el verbo "bautizar" se encuentra en tiempo pasivo, y por tanto Felipe no es el sujeto, el tenor del relato deja entrever que Felipe fue el agente ritual.

54 Sobre la figura de Felipe, cf. Matrhews, Christopher R., Philip Apostle and Evangelist. Configurations of a Tradition (=Supplements NT 105), Brill, Leiden - Boston Köln 2002. 
El v. 16, "el Espíritu Santo aún no había venido sobre ninguno de ellos; sólo habían recibido el bautismo en el nombre de Jesús, el Señor", plantea la cuestión de si Felipe practicó un bautismo sin la concesión del Espíritu. Su bautismo, tal y como se describe en la perícopa, se caracteriza en primer lugar por la ausencia explícita del Espíritu. Según la concepción lucana de la relación intrínseca entre el bautismo cristiano y el don de Espíritu, es difícil suponer que el evangelista creara esta anomalía.

Si nos preguntamos por la posibilidad histórica de un bautismo de conversión sin Espíritu, entonces tenemos más allá de la praxis misional cristiana un posible punto de referencia: Juan el Bautista, quien practicaba un bautismo de conversión en el Jordán, en marcado contraste con "el que es más fuerte que yo... quien os bautizará con Espíritu Santo" (Mc 1,7s. par.). ¿Es concebible que Felipe practicara en Samaría un tipo de ritual de iniciación cristiana, que constituyera un estadio intermedio en la evolución del bautismo de Juan a la praxis cristiana concebida por Lucas como normal a nivel eclesial, es decir, un bautismo de arrepentimiento, que tuviera claramente un carácter cristiano a través de su relación a la predicación del "reino de Dios y el nombre de Jesucristo" $(8,1.2)$, pero que como el bautismo de conversión del Bautista no estuviera relacionado a la concesión del Espíritu Santo?

Como hemos visto, esta hipótesis ya fue planteada por M. Quesnel, para quien su bautismo no estaba relacionado con la conversión ni el perdón de los pecados. No obstante, del silencio acerca del arrepentimiento y el perdón de los pecados no se puede concluir que no hayan jugado ningún papel en el pasaje; la metanoia y el perdón de los pecados, como Lucas da a entender por la vinculación terminológica entre Pentecostés y la perícopa del Bautista (Hch 2,38; Lc 3,3), constituyen la base y el fundamento que tiene en común cualquier bautismo cristiano con el rito de Juan. Este silencio pudiera deberse a que Lucas, una vez expuestas las principales características de su concepción bautismal en la perícopa de Pentecostés, evitara la repetición de particularidades. Por consiguiente, no extraña que el tema del perdón de los pecados mediante el bautismo solo se mencione en otros dos relatos de conversión posteriores, a saber, en la proclamación de Pedro a Cornelio $(10,43)$ y en el segundo relato de la conversión de Pablo $(22,16)$. La ausencia del perdón en la primera versión de la conversión de Pablo $(9,17-19)$ no nos puede llevar a pensar que Lucas tuviera en mente diferentes ritos bautismales para la conversión paulina. 
Por otra parte, la imagen de un bautismo no-pneumático de Felipe converge con lo que Hechos de los Apóstoles atribuye generalmente a la pneumatología de la corriente helenista de los cristianos de Jerusalén. Esto ha sido puesto de manifiesto en la monografía de A. von Dobbeler dedicada al evangelista Felipe ${ }^{55}$. El grupo de los Siete se compone de siete personas "llenas de Espíritu y en verdad" (6,3) y Esteban estaba lleno de "fe y Espíritu Santo" (6,5), por lo que sus oponentes no pueden resistirse al "Espíritu y a la sabiduría" $(6,10)$; en su martirio, lleno de Espíritu, tiene una visión celeste (7,55s.). Así pues, la posesión del Espíritu es el fundamento de su poderosa predicación y de la revelación profética. De forma semejante, el Espíritu dirige las actividades misioneras de Felipe, tal y como sucede en la conversión del eunuco etíope $(8,29.39)$. Ahora bien, Hechos nunca menciona, respecto a los helenistas, la transmisión del Espíritu a otras personas. Como parece, "los helenistas relacionaban el don del Espíritu exclusivamente a su propia vocación". Visto así, no extraña que el bautismo de Felipe en Samaría no transmita el derramamiento del Espíritu. Si esta indicación está en coherencia con la línea pneumatógica de los helenistas, entonces constituye una indicación de que la imagen lucana del bautismo de Felipe corresponde a hechos históricos.

Posiblemente Hech 8 permita reconocer una segunda peculiaridad que distingue la práctica bautismal de Felipe de los bautismos cristianos posteriores y mostrar una vinculación más cercana al bautismo de Juan: los bautismos de conversión de la misión a los gentiles, de los cuales el libro de Hechos informa $(10,48 ; 16,15 ; 16,33 ; 18,8)$, todos ellos se refieren a toda la casa (familia) y tienen como objetivo más o menos la creación de nuevas comunidades cristianas. En la perícopa de Samaría no se constata nada semejante. Esto puede, por supuesto, deberse a que el versículo ofrece sólo una nota sumarial y no desea detenerse en presentar un sociograma de los bautizados que vaya más allá del general "hombres y mujeres" (v. 12). Tanto más sorprendente es que el siguiente versículo informe de una relación de conversión, bautismo y seguimiento: Simón el Mago entra en una relación de 'discipulado' con Felipe, pero este motivo no explica por qué los otros samaritanos bautizados también están presentes en la escena siguiente. Si lo comparamos con el movimiento de Juan Bautista, se observan similitudes: Muchos que escuchan al Bautista, se arrepienten y reciben el bautismo sin convertirse por ello en miembros de una nueva comunidad; muy pocos entran en el círculo de discípulos de

55 Dobbeler, Axel von, Der Evangelist Philippus in der Geschichte des Urchristentums. Eine prosopographische Skizze (=TANZ 30), Francke, Tübingen - Basel 2000, 23-25.104s. 
Juan el Bautista. La falta de interés en la formación de una comunidad pudiera explicarse por la expectativa escatológica inminente o por la conciencia profética de envío a todo el pueblo, o muy probablemente se debería a ambos contextos. Que Felipe concibiera su tarea de predicación de manera similar, sería fácilmente imaginable.

Un punto de contacto entre Juan el Bautista y Felipe, pudiera ser la identidad de este último. Según el evangelio de Juan, un Felipe procedente de Betsaida fue uno de los primeros discípulos, que Jesús reunió en torno a sí, y esta llamada aconteció tras haber abandonado Jesús el seguimiento del Bautista e irse a Galilea (Jn 1,43s.). Si se asume que este Felipe -mencionado también en la lista de los Doce de los sinópticos- es idéntico, no sólo con el evangelista de Hch 8 y 21, sino que también perteneció al círculo de discípulos de Juan el Bautista ${ }^{56}$, entonces sería clara la explicación para su praxis bautismal "rudimentaria". Podría haber jugado un papel pionero, incluso en la aparición gradual de bautismo cristiano proveniente del rito del Jordán practicado por Juan.

Excepto en Hch 21,8, en ninguna parte del NT se proporcionan indicaciones adicionales, que diferencien entre sí a las dos personas con el nombre de Felipe: el "apóstol" (Mc 3,18; Hch 1,13) y el "evangelista", uno de los Siete instituidos para atender a las viudas (Hch 6,1-16). Incluso en Hch 8,1, la identificación de Felipe resulta sólo de manera indirecta al indicar que la expulsión de los cristianos de Jerusalén excluye a los "apóstoles" 57 . Por este motivo surgen voces en la investigación moderna que abogan por la identificación de ambos personajes, como es la monografía de Christopher R. Matthews dedicada a Felipe: "Tanto la visión eclesiástica antigua que distingue cuidadosamente al 'diácono' Felipe del apóstol del mismo nombre, como la moderna suposición de que había dos personas relevantes con el mismo nombre de Felipe en los albores de la Iglesia, se basan únicamente en la presentación lucana de Hechos. Si

56 Varios autores consideran que Felipe era uno de los dos discípulos de Juan el Bautista, mencionados en Jn 1,35s. En contra, Brown, Raymond E., El evangelio según Juan. I-XII, Cristiandad, Madrid 1979, 266.

57 Siempre se cuestiona por qué los apóstoles no huyeron. Hill, Craig C., Hellenists and Hebrews. Reappraising Division within the Earliest Church, Fortress, Minneapolis 1992, 32-40, es escéptico respecto al valor histórico que se debe otorgar a la persecución desatada contra los helenistas $(8,1 \mathrm{~b})$ y considera todas las posibilidad de quiénes pudieron haber sido afectados por la misma, en caso de que esta hubiera tenido realmente lugar: "Reflecting on Acts 8:1, I find it astonishing that scholars have rested so much weight on a single verse of such precariousness. The entire sequence of events it initiates is bereft of historical realism" (38s.). Según FitzMYER, Los Hechos 541, Lucas recoge una memoria histórica y da a su relato la imagen de la impávida reacción apostólica a la persecución mostrando a los cristianos cómo deben reaccionar ante las persecuciones. 
no fuera por Hechos, no habría ninguna indicación de que existiera un problema con respecto a la identidad de Felipe" 58.

Pero esta identificación de ambos personajes ya aparece testimoniada en la antigüedad. Papías ${ }^{59}$, una carta de Polícrates (190), obispo de Éfeso, así como al parecer el Stromateis de Clemente de Alejandría constituirían los testimonios más antiguos de dicha equiparación. Clasifican al padre de las hijas con dones proféticos (Hch 21,9) entre los "apóstoles", y Polícrates habla explícitamente de los "Doce Apóstoles"60. Estos autores debieron conocer el corpus lucano y conciliaron de forma diferente los diferentes pasajes que mencionan a Felipe (Lc 6,14; Hch 1,13; 6,5; 8,513; 8,26-40; 21,8). Del mismo modo, en los Hechos apócrifos de Felipe y en las listas de los apóstoles de la primitiva Iglesia se funden rasgos de ambas figuras homónimas.

Los estudios de onomástica confirman que el nombre de Felipe es poco frecuente en Palestina, en el NT y en la literatura cristiana primitiva ${ }^{61}$-para un judío de lengua aramea procedente de Betsaida pudiera explicarse el nombre por el hecho de que su lugar de nacimiento pertenecía al territorio del Tetrarca Filipo- y serían de esperar añadidos explicativos en el caso de nombres homónimos entre los discípulos y los miembros de la comunidad. Los datos onomásticos sugieren, más bien, la improbabilidad de que dos de las primeras figuras cristianas prominentes de Palestina hubieran compartido el nombre de Felipe. Según Chr.R. Matthews, la convergencia de las evidencias del segundo siglo ${ }^{62}$, los datos onomásticos y las proyecciones recientes sobre la población cristiana a

58 Matthews, Philip, 15. "In the investigation that follows I will argue that all of the references to Philip in the New Testament and other early Christian literature are most properly interpreted with reference to traditions stemming from this single figure" (3). "Far from casting doubt on the supposition that the Philip of Acts may with justice be identified as an apostle, the presence of the name Philip in the lists of the Twelve in the Synoptic Gospels, securely in fifth position, is best accounted for by this figure's early fame, owing in large part to the circulation of traditions such as those set down by Luke in Acts 8 " (127).

59 Ibid., 19-34.

60 Polícrates en Eusebio, Hist. eccl. 3.31.3 / 5.24.2.

61 ILAN, Tal, Lexicon of Jewish Names in Late Antiquity. Part I: Palestine 330 BCE$200 C E$ (=TSAJ 91), Mohr Siebeck, Tübingen 2002, 310, constata la existencia de siete personas judías con ese nombre entre los siglos III a.C. hasta el II d.C., incluyendo nuestros dos personajes del NT (en los puestos $5^{\circ}$ y $6^{\circ}$ ). Por consiguiente concluye MATTHEWs, Philip, 16s., "El testimonio limitado del nombre Felipe y su vinculación con las clases sociales elevadas ofrecen apoyo externo a la tesis defendida aquí, que el personaje Felipe de los relatos lucanos de Hechos y Felipe mencionado en los Evangelios son la misma persona" (17).

62 Para el estudio de la figura de Felipe en el siglo II, cf. Ibid., cap 1. 
finales del siglo I, hacen plausible la hipótesis de que la confusión de ambos "Felipes" tuvo su origen en Lucas.

En segundo lugar, Jn 12,20-22 narra que algunos "griegos" 63 de entre los peregrinos a la fiesta de Pascua, tenían deseo de ver a Jesús y se dirigen a un discípulo, Felipe, quien se lo dice a Andrés y los dos juntos se lo hicieron saber a Jesús. Es significativo que los griegos se pongan en contacto con los dos únicos discípulos con nombres griegos. El concepto griego debe referirse a gentiles, aunque prosélitos, en vista de la queja de los fariseos de que el mundo (kosmos) va tras Jesús $(12,19)$. El hecho de que la solicitud de los griegos se confíe a Felipe, identificado una vez más como procedente de Betsaida (12,21, cf. 1,44), cuya población gentil era significativa, plantea la posibilidad de que esta escena refleje la apropiación intertextual de tradiciones o memorias acerca de las actividades evangelizadoras de Felipe entre poblaciones gentiles ${ }^{64}$. Dado el empleo lucano de las tradiciones sobre Felipe relacionadas con el mismo tipo de actividades misioneras, pudiéramos pensar que se trate de una tradición pospascual conocida, pero retrotraída al tiempo de Jesús. Sin embargo, la utilización de Felipe y Andrés para la llegada simbólica de los griegos puede coincidir con "recuerdos" de que eran figuras importantes para la misión de los griegos. Esto se confirma en el caso de Felipe con dos tradiciones independientes, ambas centradas en la misión a los no judíos (samaritanos y etíope), y la documentación a posteriori de los Hechos de Felipe, cuyo encargo fue dirigirse a los griegos.

Si esto es así y el evangelista Lucas lo integra dentro del grupo de los "Helenistas" (Hch 6,1-6), quien misionó fundamentalmente en ciudades predominantemente de lengua griega de la zona costera $(8,40 ; 21,8) \mathrm{y}$ también convirtió a un prominente extranjero, que había llegado a Jerusalén como peregrino a la fiesta $(8,27)^{65}$, entonces el evangelio de Juan

63 Croy, N. Clayton, "Translating for Jesus: Philip and Andrew in John 12:20-22", Neotest 49 (2015) 145 - 174. Sobre el concepto de "griego" cf. M. Zugmann, Michael, "Hellenisten" in der Apostelgeschichte (WUNT II/264), Mohr Siebeck, Tübingen 2009, 1150; Mena Salas, Enrique, "También a los griegos" (Hch 11,20). Factores del inicio de la misión a los gentiles en Antioquía de Siria (=Plenitudo Temporis 9), Universidad Pontificia de Salamanca, Salamanca 2007.

64 Matthews, Philip, 116s. Dobeller, Evangelist, 286-297, ofrece una presentación de las similitudes prosopográficas de Felipe en Jn con el evangelista de Hechos.

65 Según Kollmann, Bernd, "Philippus der Evangelist und die Anfänge der Heidenmission”, en Bib 81 (2000) 551-565, Felipe se adentró de forma sistemática en aquellas regiones de Palestina que habían sido significativamente helenizadas y donde predominaba el elemento no judío de la población. En la medida en que las fuentes permiten formular un juicio, su conclusión es que en Felipe tenemos el primer misionero significativo dedicado a los gentiles. 
parece presuponer la misma identidad del discípulo de Jesús y el misionero posterior.

Como objeción a dicha identificación se podría aducir que no sería concebible que uno de los primeros discípulos de Jesús, perteneciente al grupo de los Doce, después de Pascua se cambiara a la formación de los "Siete". En cualquier caso, la presentación de Lucas no da la impresión de que el círculo de los Doce hubiera sobrevivido mucho más tiempo tras la creación de ese segundo órgano de gobierno. Precisamente en relación con la institución de los Siete son mencionados los Doce por última vez $(6,2)$.

La posibilidad, sin embargo, de que el evangelista de Hch 8 hubiera podido pertenecer antes de Pascua a los discípulos de Jesús, tampoco está excluida, si la distinción entre los dos Felipes lucanos es históricamente cierta.

\section{Conclusión}

Supuesto el caso de que las hipótesis contempladas previamente son correctas, entonces resultaría aproximadamente el siguiente escenario ${ }^{66}$ : Felipe -quien posiblemente antes de Pascua ya pertenecería al círculo de los discípulos de Jesús y anteriormente tal vez habría estado cercano a Juan el Bautista- participó después de Pascua como miembro destacado y dirigente de la corriente helenista expulsada de Jerusalén con un papel activo en la difusión del mensaje cristiano. En esta misión exigió el bautismo a quienes se convirtieron a la fe en el Señor resucitado. A diferencia de Juan, cuya actividad se mantuvo vinculada al Jordán, Felipe, quien actuó como predicador itinerante $(8,26.40)$, bautizó donde se le ofreció la oportunidad. Como el bautismo de Juan en el Jordán, el bautismo de Felipe era fundamentalmente un "bautismo de conversión para el perdón de los pecados", el cual difería conceptualmente en términos explícitos respecto al de Juan, en cuanto que se realizaba de forma explícita en el nombre de Jesús. En contraste con la práctica, que más tarde se convirtió en norma, el bautismo de Felipe no estaba vinculado a la recepción del Espíritu Santo. Tampoco tenía como objetivo la constitución de nuevas comunidades locales ni la integración de nuevos miembros en las comunidades ya existentes; por consiguiente, no constituía -al menos en este sentido sociológico- un ritual de iniciación. Sin embargo, parece que

\footnotetext{
66 Tesis propuesta por AVEMARIE, Die Tauferzählungen, 264ss.
} 
se encontraba en camino de desarrollo hacia este tipo, pues el curso del relato implica que los convertidos por Felipe continuaban en contacto entre sí.

Es difícil demostrar de Hch 8, si en el bautismo de Felipe ya se empleaba una fórmula que mencionara el nombre de Jesús. No se excluye, sin embargo dado que "en el nombre del Señor Jesús" en 8,16 sigue la tradición lingüística de Lucas testimoniada también en 19,5; es difícil decidir si la expresión ya estaba anclada en la tradición prelucana. En principio, es concebible un bautismo cristiano en el que la referencia a Jesucristo como Señor resultara simplemente de la predicación y la conversión y no se considerara necesaria una referencia explícita significativa del rito. Tampoco Juan el Bautista empleaba, si se puede concluir del silencio de nuestras fuentes, una fórmula ritual. $\mathrm{Si}$, por otra parte, como se cree comúnmente, el rito cristiano del bautismo fue desarrollado a partir del realizado por el Bautista ${ }^{67}$, así se podría suponer un período de transición para la introducción de una fórmula basada en el nombre.

El punto más débil de esta hipótesis es la identidad de Felipe el evangelista con el discípulo del mismo nombre perteneciente al grupo de los Doce y su pertenencia originaria al círculo de los seguidores del Bautista. En realidad no cambia gran qué, si la dejamos de lado: Incluso cuando el evangelista de Hch 8 se uniera sólo después de Pascua a los discípulos de Jesús, es fácilmente posible que su bautismo represente una etapa intermedia en el desarrollo del ritual bautismal desde Juan al ritual cristiano. Menos probable es sólo entonces que Felipe fuera uno de los primeros en adaptar el bautismo de Juan a la nueva realidad pospascual. De cualquier manera, Felipe no fue el único agente ritual del bautismo en los albores de las comunidades cristianas. El tipo de bautismo, que es evidente en la perícopa Samaría, podría haber sido el bautismo predominante en el círculo de los helenistas, al que perteneció a Felipe, e incluso en la Iglesia de este período inicial, aunque eso nunca se podrá verificar.

Aunque nos faltan muchos datos para poder corroborar lo expuesto, sin embargo ello confirmaría lo que los nuevos estudios sobre la configuración de los rituales de la iniciación cristiana constatan, que esta se caracterizó por la diversidad y variedad distintiva de prácticas iniciáticas, ya que en el cristianismo primitivo confluían diferentes tradiciones en

${ }^{67}$ LABAHN, Michael, "Kreative Erinnerung als nachösterliche Nachschöpfung. Der Ursprung der christlichen Taufe", en: Hellholm, David - Vegge, Tor - Norderval, Oyvind - Hellholm, Christer (eds.), Ablution, initiation, and baptism. Late antiquity, early Judaism, and early Christianity (=BZNW 176), De Gruyter, Berlin - Boston 2011, 337-376. 
desarrollo y evolución, cada una de las cuales con sus propios modelos rituales, estructuras y teologías, dependiendo de las diversas localizaciones geográficas, tradiciones culturales y lingüísticas. El bautismo de Felipe pudo constituir una de esas líneas iniciales, que con el tiempo se amalgamó con otras y desapareció, aunque ha dejado su huella en el texto lucano, fruto tal vez de las fuentes previas que el primer historiador cristiano empleó para la composición de su obra. 